MMXVII VOL. VIII. NR. 4

\title{
A DEBRECENI REFORMÁTUS KOLLÉGIUM TEOLÓGIAI OKTATÁSÁNAK TÖRTÉNETE 1850-1912. A TEOLÓGIAI AKADÉMIA A KOLLÉGIUM OKTATÁSI RENDSZERÉBEN
}

\begin{abstract}
The History of Theological Education at Debrecen Reformed College between 1850 and 1912. The changes in the educational system of Theology at Reformed College of Debrecen were heavily influenced by the political-social events of historic Hungary between 1850 and 1912. The first date signals the introduction of arbitrary rule of the Habsburg monarch who suppressed the Hungarians during the War of Independence in 1848-49. The closing date is the emergence of a new state run university in Debrecen. The study throws light on how the Organisations Entwurf tried to modernize as well as Germanize the education system in the Habsburg Empire. As a result, the traditional education structure at the College was entirely restructured. It brought about the disintegration of humanity and art faculty into a grammar school thereby only the law and theological faculties were left intact for a while. The Reformed Church District strongly protested against the dismantling its more than 300 years old education system. It is the irony of history what the oppressing Austrian could not achieve, it was realized after the Compromise by József Eötvös, the Hungarian minister of culture, religion and education. Needless to say that education at all levels needed to be modernized and standardized. It is clear that it had a positive impact on the curricula of Reformed theological education in the long run. The paper introduces briefly the life of theological professors, their career with a view to their studies abroad and finally their works at various departments of theology.
\end{abstract}

A nemzeti műveltség jelentkezésének és kibontakozásának korában a Debreceni Református Kollégium számos területen gazdagította a magyar kultúrát. ${ }^{1}$ A reformkor betetőzése az 1848-as áprilisi vívmányok voltak. Ezeket azonban fegyverrel kellett megvédeni az 1848-49-es szabadságharcban, amely egy új korszak nyitányát jelentette, még akkor is, ha bukással végződött. Ezt követte a neoabszolutizmus korszaka, majd amikor a politikai helyzet változott, a külpolitikai események mégiscsak kiegyezésre kényszerítették az osztrák hatalmat 1867-ben.

A szabadságharc alatti kollégiumi történésekről a hivatalos forrásokból keveset tudunk, hiszen "felsöbb intézkedésre a szabadságharcra vonatkozó dokumentumokat meg kellett semmisiteni”. ${ }^{2}$ Révész Bálint a gyakorlati teológia tanára és debreceni lelkész 1848.

${ }^{1}$ Bajкó Mátyás, A nemzeti müveltség jelentkezésének és kibontakozásának kora (1804-1849) = A Debreceni Református Kollégium története, szerk. BARCzA József, Budapest, 1988, 151 kk.

2 Czeglédi Sándor, A teológia tanitása a Kollégiumban = A Debreceni Református Kollégium története, i. m., 566. Ezt jól mutatják a tanárkari és egyházkerületi jegyzőkönyvekben üresen hagyott lapok. Czeglédi sajnos nem jelöli, meg hogy milyen forrás alapján állítja ezt. 
március 23-án nyolc pontos kiáltványt fogalmazott meg a politikai szabadelvüségnek és az intézmény polgári szellemben történő demokratikus továbbhaladásának jegyében. ${ }^{3}$ A visszaemlékezések szerint a kollégiumban megrendelték Kossuth Hírlapját. A diákok tanulótársaikból zászlóaljat alakítottak, amelyet 1848. március 26-án az Emlékkertben fel is avattak. Itt Péczely József tanár tartott ünnepi beszédet zuhogó esőben. ${ }^{4}$ Ő nemzeti liberális szellemben tanította a diákokat, és rájuk gyakorolt hatása maradandó volt. ${ }^{5}$ A szabadelvűség szellemének, a polgári haladás gondolatának nemcsak a diákifjúság, hanem a tanártársak között is voltak hívei. „Péczely, Kerekes a reformkorban, majd Lugossy József, Szücs István és Zákány József 1848-49-ben a forradalmi szellemü diákifjuságot együttérzéssel, rokonszenvvel bátorítják; annak ellenére, hogy az Egyházkerület, személy szerint Szoboszlai Pap István püspök - akárcsak nagy elödje, Budai Ézsaiás - Bécs irányában rugalmas, diplomatikus iskolapolitikát kénytelen folytatni." 6

A dicsőséges szabadságharc alatt, 1848 májusától szünetelt a tanítás a Debreceni Református Kollégiumban az egyházkerületi közgyűlés rendeletére. ${ }^{7}$ A tanárok közül Péczely Józsefet és Török Józsefet delegálta a főiskola az augusztusi pesti miniszteri értekezletre. ${ }^{8} \mathrm{~A}$ diákok, különösen a jogász hallgatók katonai gyakorlatokat tartottak, $s$ „erre a tanári kar tekintettel volt, söt a rendkivüli körülmények miatt a kello" nyugodtság a tanulásra hiányozván, de meg a szülék is a viharos idök miatt maguk körében óhajtván látni gyermekeiket, személyesen kérték a tanárok a superintendensnél az iskolai év május 31-[sic] berekesztését". I'gy a kollégiumban a "föiskola másfél évig zárva volt". ${ }^{10} \mathrm{~A}$ kollégium életét és a relatív csendet a magyar politikai élet Debrecenbe kerülése rázta fel 1849. január 7-től kezdődően. ${ }^{11} \mathrm{~A}$ intézmény épülete 1849 elejétől az országgyűlésnek adott otthont. ${ }^{12} \mathrm{~A}$ képviselők az oratóriumban tanácskoztak, és a kollégiumban ren-

${ }^{3}$ Balogh Ferenc, A Debreceni Református Kollégium története adattári rendszerben, Debrecen, 1904, 478. n. 15.

${ }^{4}$ BALOGH István, $A$ szabadságharc küzdelmes hónapjaiban = Debrecen története, 2, szerk. Rácz István, Debrecen, 1981, 478.

${ }^{5}$ Balogh, A szabadságharc..., i. m., 478.

${ }^{6}$ Bajкó, i. m., 186.

7 Czeglédi, i. m., 566. Vö. még TtREL (TtREK jkv. 1847. márc. 22.-1848. július). Nincs bejegyzés 1848. május 12-én fols. 656-657. Továbbá: A Tiszántúli Református Egyházkerület jegyzökönyve 1848. júl.-1850. szept. (jelzet: Z-20) 1848. november 8. (fol. 154-ig) és 1849. április 12. között (fol. 157) nincs bejegyzés. A 156 -os és 157 -es oldalak üresen állnak.

${ }^{8}$ A Tiszántúli Református Egyházkerület jegyzökönyve 1848 júl.-1850. szept. (1848. július 3. 210. szám), fols. 679-680. TtREL, I 1-c-19.

9 Tanárkari jegyzökönyv 1847. nov. 13.-1851 november 8., (1848. május 12., 1623 szám.) 1-256 fols. (fol. 64), TtREL, II. 1.d.11.

${ }^{10}$ BALOGH, Adattár, i. m., 449.

11 Szabó István, A szabadságharc fövárosa Debrecen, Debrecen, 1948, 484.

${ }^{12}$ Czeglédi, i. m., 566. Czeglédi tévesen azt állítja, hogy csak 1850-ben nyitotta meg a kollégium a kapuit a diákok előtt. Ezzel szemben a kortárs Balogh Ferenc arról írt, hogy már 1849. november 5-én folytatódott az oktatás! Valószínű, hogy a szabadságharc utáni megtorlások miatt nincs egyházkerületi jegyzőkönyv 1849. szeptember 26. (I. 1-a-20.) és 1852. június 28. között (I.1-a-2. Ez a második kötet). 
dezkedett be az állami pénzverőmühely és a bankjegynyomda is. ${ }^{13} \mathrm{~A}$ magyar nemzet függetlenségéért az iskola sokat tett, amit az is mutat, hogy diákjai és tanárai részt vettek a szabadságharcban, valamint az, hogy egy ideig maga az ősi kollégium volt az egész történelmi Magyarország központja. ${ }^{14} \mathrm{~A}$ forradalom évében az akadémia három felső osztályában 416 diák tanult, akik közül - ahogy már említésre került - Széll János és Kapros Sámuel vezetésével 171-en megalakították a nemzetőri századot. ${ }^{15} \mathrm{Nem}$ csak diákok vettek részt a szabadságért vívott küzdelemben, de a tanárok közül Lugossy József is ott volt mint lovas nemzetőr az aradi táborozásban. Révész Bálintot, a gyakorlati teológiai tanszék tanárát, későbbi esperest (1861) és püspököt (1871) Szűcs Istvánnal a diákok tervezett nemzetőrszázada tisztségviselőjének választották 1848-ban. ${ }^{16}$ Révész és Könyves Tóth Mihály népgyűléseken bátorította a város népét az 1849-es esztendőben. ${ }^{17}$

1849. január 6-tól Lugossy József után a könyvtár felügyeletét id. Révész Imre vette át. Júliustól a kollégium a megszálló, a magyar függetlenséget letipró orosz katonák hadikórházaként müködött. ${ }^{18} \mathrm{~A}$ későbbi debreceni lelkipásztor ${ }^{19}$ bátor kiállásának köszönhető, hogy a felbecsülhetetlen értékű könyvtár anyaga száz évvel utána, ugyancsak az orosz megszállásnak kitett sárospataki kollégium kincsei sorsára nem jutott. ${ }^{20} \mathrm{~A}$ kollégiumban az oktatás 1849. november 8-tól indult meg ismét. A Nagytemplomban „Révész Bálint hittanár által szolgáltatott isteni tiszteleten a' Szentlélek segitségül hivásával és a felséges uralkodóház és dicsöséges uralkodó 1sö [sic] Ferencz József cs. és király állandó és hosszú országlásáért tartott buzgó könyörgés mellett az iskolai tanév à szokott ünnepéllyel megnyittatott." ${ }^{21}$ A jegyzőkönyv írója nem is gondolta, hogy a forradalmat pártoló Révész kötelességszerủ kérése mennyire meghallgatásra fog találni.

Haynau terrorja és a Bach-féle politikai rendszer kiépülése a kollégium életére is kihatott. A szabadságharc bukása után az egyházkerület és a kollégium vezetői később

13 Szabó, A szabadságharc fövárosa..., i. m., 133.

${ }_{14}$ Balogh, A szabadságharc..., i. m., 482.

15 A Uo., 478.

${ }^{16}$ Csohány János, A korszakváltás évszázada (1850-1950) = A Debreceni Református Kollégium története, i. m., 212. nr. 62. Idézi ZováNYI Jenő, A Tiszántúli Református Egyházkerület története, Debrecen, 1939, 175-176; Szabó József, A debreceni református kollégium tanárai és kiválóbb növendékei: 1549-1925, Debrecen, 1926, 36; NAGY Sándor, A Debreceni Kollégium mint egységes intézmény az Egyetem kiválásáig, Debrecen, 1940, 233.

17 A Tiszántúli Református Egyházkerület jegyzökönyve 1847-1848 júl. (1848. március 22., 77. szám), fols. 1-738 (fols. 533-4). TtREL I. 1-a 19. XVIII.k. (Z-19).

18 Révész Imre iff., Révész Imre élete 1826-1881, Debrecen, 1926, 23.

19 ZovánYI Jenő, Magyarországi protestáns egyháztörténeti lexikon, szerk. LaDÁNYI Sándor, Budapest, 1977³, 566. Révész 1856-tól lett debreceni lelkész. Elötte 1851-től Balmazújvárosban lelkész, majd 1854 májusától Szentesen és végül Debrecenbe került.

${ }^{20}$ Révész, Révész Imre élete, i. m., 23. Ezt a kincset a Szovjetunió örököseként élő orosz állam részben visszaszolgáltatta, amelyért a hálás református közönség külön ünnepségben emlékezett meg.

21 Tanárkari jegyzökönyv 1847. nov. 13.-1851. nov. 8., (1849. november 8., 35. szám), fols. 1-256 (fol. 89)., TtREL II. 1.d.11. „A Kollégium csak 1850-ben, a szabadságharc bukása után nyitotta meg kapuit újra a diákság elött" - írja tévesen CzEGLÉDI, i. m., 566. 
megértéssel és nagy segítőkészséggel vették körül azokat, akiket az abszolutizmus megtorló intézkedései ellen védeni kellett. ${ }^{22}$ Természetesen nem tudtak mindenkit megvédeni. Könyves Tóth Mihály és még sokan mások várbörtönbe kerültek. A tanári kart és a kollégium vezetőit a neoabszolutizmus kormánya figyeltette, különösen a történelemtanárt. ${ }^{23} \mathrm{Az}$ elbukott szabadságharc miatt nagyon nagy volt az elkeseredés. A diákok többször is kint maradtak az esti kilenc órai kapuzárás után, és összetűzésbe kerültek a csendőrökkel. Emiatt a városi tanács külön kérvényben kérte a tanári kart, hogy a tilalmat a „szokásos nyomtatási rendelettel” közölje a diákokkal. Különösen a „Tigris” nevű fogadóban történt sok konfliktus. ${ }^{24}$ Bár a tanári kar minden eszközzel igyekezett óvni és védeni diákjait, az állami büntetések rendkívül kemények voltak. Egyik diákot, Balogh Lajost tíz évre a gránátos ezredbe sorozták, „ott a kemény szolgálat elzsibbasztotta, s kiszabadulta után, haláláig megérezte kedélye a hivatott pályáról eröszakos leszoritást". ${ }^{25}$

1853-ban sorra születtek a nemzeti érzést gúzsba kötő rendeletek is. Január 26-án az igazgatóknak és tanároknak adott zenés, illetve jelzésekkel kifejezett tisztelgést tiltotta meg az állam. Magyarország helytartója a 3864. számú rendeletében eltiltotta a Kossuth kalap viseletét. Végül pedig Szoboszlai Pap István szuperintendens elutasítás és büntetés terhe alatt megtiltotta a diákoknak a (Kossuth) szakállviselést 1853. május 7-én. ${ }^{26}$ Ezzel a bölcs és előrelátó püspök megelőzte a helytartótanács néhány hónap múlva kiadott rendeletét. ${ }^{27}$ Balogh Ferenc, későbbi teológiai tanár, aki egy évvel később kezdte meg debreceni tanulmányait a teológián, úgy vélekedett, hogy a tanári kar „igen alatta állt Szoboszlai varázsának, erös kezének, ki csaknem diktátorként intézkedett". 28 Zsigmond Ferenc is hasonlóképpen vélekedik: „a tanári kart a püspök erélye és tekintélye vasfegyelem alatt tartotta, de 1855-ben meghalt Szoboszlai, s a kollégiumi közszellem mintegy felszabadult a nagy nyomás alól". ${ }^{29}$ Egyértelmü, hogy óriási politikai nyomás helyeződött az egyházi vezetésre, különösképpen a szuperintendensre, aki roppant szigorával bizonyára védte is azokat, akik intézkedéseit diktatórikusnak tartották. A fenti, citált példákból láthattuk, hogy akár egy évtizedig tartó katonai szolgálat vagy börtön volt büntetése az államhatalommal szembeszegülőknek, valamint azt is, hogy a tanári kar és a superintendens is védte az egyház tagjait. ${ }^{30}$

A Bach-rendszerben nem a viseletet és hétköznapi beszédet szabályzó rendeletek voltak a legveszélyesebbek a nemzet és a kollégium életére nézve. A legnagyobb befolyással a Leo Thun gróf által kezdeményezett oktatásügyi politika, az Organisations-

${ }^{22}$ Czeglédi, i. m., 566.

${ }_{23}$ Zsigmond Ferenc, A Debreceni Református Kollégium története 1538-1938, Debrecen, 1938, 178.

${ }^{24}$ Tanárkari jegyzökönyv, (1852. október 23., 45. szám), fols. 7-8. TtREL, Tanárkari gyülések jegyzökönyve 1852. október 2.-1855. július 31., TtREL II. 1-d.13.

25 BalOGH, Adattár, i. m., 291.

${ }^{26}$ Uo.

27 Zsigmond, i. m., 177.

${ }^{28}$ BAlogh, Adattár, i. m., 292.

29 Zsigmond, i.m., 178.

30 További történetekre lásd BALogh, Adattár, i. m., 290-293. 
Entwurf bírt, amely egyrészt modernizációra törekedett, másrészt azonban egyértelmüen németesítéssel próbálkozott ismételten a hosszú és csendes ellenreformáció után. ${ }^{31}$ Csorba László találóan megfogalmazta a debreceniek érzését: „A részleteiben valóban modern intézkedések nem kárpótolták a hiveket az iskolai és egyházszervezeti autonómiájuk súlyos sérelmeiért." 32

Az Entwurfot 1850-ben vezették be országosan, amely közvetett hatással lett a teológiai oktatásra is. A lelkészképzés jogállása nem változott. Egyházi magániskolaként működhetett tovább a teológiai akadémia, és a felügyeleti jogot felette a Tiszántúli Ref. Egyházkerület gyakorolta. Az egyházkerületi közgyűlés a gimnázium felállítását és a jogakadémia létrehozását 1852. július 1-jén rendelte el. ${ }^{33}$ Azonban csak 1853 őszétől tudott eleget tenni a Thun-féle osztrák mintájú gimnázium felállítása kritériumainak, mert többek közt olyan tanárokat kellett kinevezni, akik nem voltak bölcsésztanárok. ${ }^{34}$

Ezzel a régi három lábon álló egységes bölcsészeti, jogi és teológiai képzés megbomlott, és a debreceni kollégium háromszáz év óta fennálló szervezetének átalakulását eredményezte. Az ősi hagyományok ilyen formájú megszüntetése és a vele járó németesítési törekvés a magyar reformátusság komoly ellenszenvét vívta ki. Mindezek a politikai törekvések a nemzetiségeknek kedveztek és a magyarságot hátrányosan érintették. Az oktatásbeli változások azonban a birodalom centralizációja és modernizációja miatt elengedhetetlenek voltak. A tanügyi törekvések mégiscsak a modern oktatás alapjait igyekeztek megteremteni.

A hagyományos rendszerben az elemi, közép és felső tagozatok határai csak nagyjából voltak megvonva. ${ }^{35} \mathrm{Az}$ oktatás csúcsán a bölcsészet, jog és teológia hármas egysége állott, ahol még mindig a teológia volt a legmeghatározóbb a század közepén. A professzorok az oktatást valójában csak a felső tagozatokon végezték, míg az alsóbb szinteken az idősebb diákok tanítottak. Az Entwurffelszámoltatta a kollégium korábbi hatéves tagozatát (korábbi középszint), és a felső tagozat kétéves (bölcseleti) kezdő évfolyamait gimnázium néven egyesítette. Az ennek eredményeként létrejövő 8 éves oktatási rendszert 4-4 éves al- és felgimnáziumra tagolta. A miniszter a nyilvánossági jogot komoly feltételekhez kötötte. A rendes tanárok száma legalább tizenkét fő kellett, hogy legyen, akiknek a fizetését az állam meg is szabta. A szakképesítést állami bizottsághoz kötötte, továbbá kötelezte az új iskolákat külön igazgató alkalmazására, módszertani újításokat is hozott, amely a szakképzésre tette a hangsúlyt. Elöírta a nyolcadik év végén kötelezően leteendő érettségi vizsgát, és a középiskolában a reáltantárgyak megerősítése miatt még jól berendezett szertárt is kellett létesíteni. Az új nyolcosztályos gimnáziumi

31 Bucsay Mihály, A protestantizmus története Magyarországon 1521-1945, Budapest, 1985, 110-118. Vö. még Ábrahám Kovács, Counter Reformation = Encyclopaedia of Mission and Missionaries (Religion and Society series Part 1), New York, 2007, 107-109.

32 Csorba László, Az önkényuralom kora 1849-1867 = A 19. századi magyar történelem, 1790-1918, szerk. Gergely András, Budapest, 1998, 327.

33 CsohánY, i. m., 209.

${ }^{34}$ Uo.

35 Zsigmond, i.m., 175. 
oktatás a jogakadémiához hasonlóan, 1853 őszén indult meg. ${ }^{36} \mathrm{Az}$ átszervezés miatt a bölcsészeti felső tanfolyamok beolvadtak a gimnáziumba, a jogi oktatást külön, önálló akadémiává kellett szervezni, ahol szintén szigorú feltételeket szabott az állam. Négy rendes tanárt kellett alkalmazni, az állam itt is meghatározta a tanárok fizetését, és csak a minisztérium által elfogadott tantárgyakat lehetett oktatni meghatározott óraszámban és terjedelemben.

A neoabszolutizmus oktatási rendszere egyedül a teológiai oktatást hagyta érintetlenül, mert a hitéleti dolgok feszegetése mindig is a legérzékenyebb kérdések közé tartozott. Ez azt eredményezte, hogy a teológiai tanárok felkészültségét az állam nem vizsgálta, nem írta elő nekik, hogy milyen tankönyvekből oktassanak, hány órát tanítsanak, és nem kötelezte őket tankönyvírásra, valamint a fizetésüket se szabályozta. Az utóbbiakat azonban az egyházkerület, ha nem is azonnal, de szép lassan a kor haladó programjának hatására rendezni kezdte, először 1860-ban, majd tíz évvel később. ${ }^{37} \mathrm{Az}$ oktatásbeli modernizáció a teológiai oktatásra is lassan, de visszahatott. A peregrinus diákokból lett professzorok a modern oktatási elvárásoknak megfelelően készültek fel az előadásokra, könyveket jelentettek meg, fordításokat közöltek, és önképzőköröket hoztak létre.

Az említett hatásoknak köszönhetően a teológiai 'szak' önkéntelenül vált önállóvá. Pótolni a kellett az első évfolyamot, akik korábban egyszerre másodéves joghallgatók is voltak. Ezen kívül az akadémia létéhez, amely addig hároméves volt, szervezniük kellett egy negyedik évfolyamot is. Így a képzés a korábbiaktól eltérően és az új jogi akadémiához hasonlóan háromévesről négyévesre változott. A megváltoztatott oktatási struktúrában az első tanévet az 1853-54-es oktatási év jelentette: „A teológia elsö igazgatója a bölcsészetet oktató Török József, kollégiumi orvos volt." ${ }^{38}$ Csohány János szerint: „ezen nem kell meglepödni, hiszen az addig egységes akadémiában az igazgatói teendöket vagy teológiai, jogi, illetve bölcsészeti professzorok látták el. Ez azért is maradhatott meg, mert a teológiai képzésben számos tantárgyat továbbra is maguk a jog-és bölcsészprofesszorok látták el." 39

„A bölcsészeti tantárgyak mintegy lefelé irányuló mozgással beolvadtak a gimnáziumba és az mint akadémiai, azaz felsö tagozat megszünt. A tanárokat viszont az egyházkerület megtartotta, hiszen a jogi és teológiai felsöoktatásban megmaradtak a bölcsészeti tantárgyak: az irodalom, filozófia, történelem és a nyelvek. Jó példa volt erre Lugossy József esete, aki eredetileg magyar irodalmat oktató professzor volt, de az ötvenes években a hittanhallgatóknak ö tanitotta a héber, arám, arab, szir, perzsa nyelvet." "40

36 Uo., 177.

${ }^{37}$ BALOGH, Adattár, i. m., 79. Az akadémiai tanárok fizetése $824 \mathrm{Ft}$ volt, amely $724 \mathrm{Ft}$ alapfizetésből és $100 \mathrm{Ft}$ kiegészítésből állt. Ezen felül volt még $210 \mathrm{Ft}$ lakáspénz. 1870-től pedig $1100 \mathrm{Ft}$ lett az akadémiai tanár fizetése.

38 Balogh, Adattár, i. m., 517.

39 CSOHÁNY, i. m., 209.

40 Uo. 
Az értesítőkből és különféle jegyzőkönyvekből, valamint a kortárs, Balogh Ferenc írásaiból tudjuk, hogy többen is tanítottak bölcsészeti tantárgyakat a teológián. Thót Ferenc görög és latin irodalmat, valamint neveléstörténetet, Vecsei József filozófiai jellegű tárgyakat, Veress László elméleti és gyakorlati pedagógiát és francia nyelvet. Kallós Lajos történelmet és latin irodalmat tanított, mert Vecsei 1855-ben meghalt, és Thót átkerült az elhunyt tanszékére, Kallós pedig átvette Thót tárgyait. ${ }^{41}$ A hallgatók ezenkívül statisztikát tanultak Búzás Páltól. Hasonlóképpen a jogi oktatást is a korábbi jogprofesszorok vitték tovább a teológus ifjak számára, akiknek az egyházkormányzati és társadalmi tevékenységükhöz elengedhetetlenül fontos volt a jog ismerete. Így Szűcs István jogtanár tanította nekik az egyházjogot. A szervezeti elkülönülés ellenére az állások megmaradtak, és az oktatás sem sérült alapjaiban. Sőt, a Thun által elindított, majd Eötvös révén magyar testre szabott felsőoktatási reformok később pozitívan hatottak a teológiai oktatásra, de ezt az önkényuralom éveiben még nem láthatta senki.

Az abszolutizmus elleni harc tetőpontja a protestáns pátens elleni küzdelem volt. ${ }^{42}$ Csak a pátensharc után, 1861-ben állt vissza a kollégium akadémiai tagozatainak egysége. ${ }^{43}$ A jogakadémiát, amely 1856-ban bezárt, mert nem kívánták a tantárgyakat németül tanítani, ${ }^{44}$ az egyházkerület 1861. év áprilisi 61. számú rendelete helyezte viszsza régi helyére. ${ }^{45} \mathrm{~A}$ teológia, a helyreállított jogi és bölcsészeti szak együtt jelentette az akadémiát, amit a debreceniek szívesen neveztek föiskolának is. A bölcsészeti szak azonban már 1853-ban beolvadt az egy filozófiai tanszék kivételével a nyolcosztályos gimnáziumba. A bölcsészeti tanfolyam önállóvá szervezése Balogh Péter püspök és az egyházkerület szívügye lett, hiszen protestáns egyetemet szerettek volna létrehozni. Ez az álom csak évtizedekkel később valósulhatott meg. ${ }^{46}$

Az akadémia tanárai 1861-től ismét egy tanári karba tartoztak szervezetileg, amelyet egy választott igazgató irányított. A tanárok a régen bevált módszer szerint megosztották a munkát. Nem volt elvárás, hogy egyes tanszakokon csak azok a tanárok oktassanak, akiknek a tanszékeit annak a tanszaknak a profiljára alapítottak. A bölcsészeti tárgyakat bölcsésztanárok adták elő mindhárom tanszakon. „Sőt a keleti nyelvek közül a bibliai hébert is Lugossy József oktatta, amikor meggyógyulva újra munkába állt (18771884). Azt természetesen a teológusok tanulták. A jogi tárgyak oktatói a teológián is jogi professzorok voltak és teológiai professzor tanitotta egyháztörténelemre a jogászokat." "i7 Így a kollégium különböző felsőoktatási intézményei szervesen összekapcsolódtak, és annak tanárai szorosan együttműködtek. Ők együtt formálták a leendő református lelkészek

${ }^{41}$ Balogh, Adattár, i. m., 456, 517-521.

42 Barátr Béla, A protestáns pátens és kora, Debrecen, 2010.

43 ZovánYI Jenő, A Tiszántúli Református Egyházkerület története, Debrecen, 1939, 126. Lásd még ZsigMOND, i. m., 180. Továbbá CsoHÁNy, i. m., 246.

44 Zsigmond, i. m., 178.

${ }^{45}$ Egyházkerületi jegyzőkönyv 1860. okt.-1871. aug., (1861. április, 61. szám), p.15. TTREL K 439/4.

46 Zsigmond, i. m., 181.

47 CsohánY, i. m., 246. 
és tanárok szellemiségét, közvetítve az eltérő szellemi irányzatokat, de mégis ragaszkodva a protestáns, kálvinista hagyományokhoz.

A főiskolán zajló változásokat az egyházkerület Főiskolai Főfelügyeleti Bizottmánya irányította, amelyet az egyházkerület 1861-ben állított fel. ${ }^{48} \mathrm{~A}$ kerület vezetése élén Balogh Péter superintendens és gróf Dégenfeld Imre a kollégiumi vezetőkkel egyetértésben a föiskola egész rendszerét alapjaiban igyekezett megreformálni. Szép példája az önkéntesség protestáns elvének, hogy a főiskola részéről Zsombori Imre, aki a Gazdasági Tanács kurátora, azaz elnöke volt lemondott a tiszteletdíjáról, és azt a kollégium közszükségleteire felajánlotta. ${ }^{49}$

1861-től egészen 1872-ig a tantervek, iskolai törvények, szabályzatok és új tanszékek kialakítása volt folyamatban. Az oktatás azonban továbbra is az ősi kollégiumi keretek közt folyt, és majd csak 1873-74-től vált véglegessé a nyolcosztályos gimnázium. Érdekesség, hogy amit a németesítő Entwurft nem tudott elérni, azt az új magyar oktatásrendszer valósította meg a kiegyezés után. A változtatás, mint láttuk, a „bölcsészeti tanfolyamnak életébe került". ${ }^{50} \mathrm{Az}$ Eötvös-féle reformok hatására az egyházkerület tanügyi bizottsága véleményeztette a tanári kart, hogy a Magyar Irodalmi Tanszék áttehető-e a gimnáziumba. Ennek következményeként a régi rendszer bölcsészeti első és második évfolyama átkerült a gimnáziumba. A tanszékre Géresi Kálmánt választották meg. ${ }^{51}$

Ahogy láttuk, az állami törvények is jelentősen befolyásolták a kollégium és benne a teológiai akadémia életét a neoabszolutizmusban. A kiegyezés után pedig a modern magyar államiságot megteremtő oktatásbeli rendelkezések, törvényjavaslatok formálták az egész intézmény arculatát. Az egyházkerület tanügyi bizottsága számos intézkedést ajánlott a kerület figyelmébe már 1874-ben, majd ezt később is megerősítették konkrét intézkedési javaslatokkal. A cél az volt, hogy a: „magyar protestáns egyetem vagy fötanoda megvalósitásához vezetö elsö lépcsőt", a kollégiumban működő akadémiát tovább fejleszsze „azt a tudomány mai követelményeinek megfelelöleg [sic] lehetöleg úgy szervezi, hogy a versenyt más hasonnemü ily intézetekkel bizton kiállhassa. "52 Ebbe az újításokat hozó kezdeményezésbe helyezhető be a főiskolai tanárok kérelme, hogy az egyházkerület konventi küldöttei között ők is képviseltethessék magukat. ${ }^{53}$

Az újabb strukturális meghatározó változásra az 1890-es években került sor. Balogh Ferenc találóan idézte Bod Péter prófétai szavait, miszerint a szomorú harc és könnyek

${ }^{48}$ A Tiszántúli Református Egyházkerülete jegyzökönyve 1860. okt.-1871. aug. (1861. április, 62. szám.), p.15. TTREL, K 439/4.

${ }^{49}$ A Gazdasági Tanács jegyzökönyve (1859. 210. sz). Idézi Balogh, Adattár, i. m., 329.

50 Zsigmond, i.m., 180.

${ }^{51}$ A Tiszántúli Reformált Egyházkerület Debrecenben 1875. április 15., 16., 17. és 18-dik napjain tartott elsö közgyülésének jegyzökönyve (1875. ápr. 17. szám), 5-6.

${ }^{52}$ A Tiszántúli Reformált Egyházkerület Debrecenben 1875. április 15., 16., 17. és 18-dik napjain tartott elsö közgyülésének jegyzökönyve (1875. ápr. 58. szám), 20.

53 A Tiszántúli Reformált Egyházkerület Debrecenben 1875. április 15., 16., 17. és 18-dik napjain tartott elsö közgyülésének jegyzökönyve (1875. ápr. 66. szám), 23-4. 
után a föiskola 'virágkora', ahogy a tizennyolcadik században történt, most, a tizenkilencedik század végén 'ismét visszajött'. ${ }^{54} \mathrm{~A}$ kortárs teológiai tanár párhuzamot látott Domokos Lajos főiskolai gondnok, Budai Ézsaiás hittanár és Rhédei Ferenc fögondnok a 18. század végén a kollégiumért kifejtett reformmunkássága és Baczoni Lajos dékán, jogtanár, valamint a Révész Bálint püspök mellett fögondnokként dolgozó gróf Dégenfeld József föispán érdemei között. ${ }^{55}$

A Debreceni Református Kollégium felső, akadémiai tagozatait 1892-ben kétfakultásúvá szervezték át, külön-külön dékáni hivatallal. ${ }^{56} \mathrm{Az}$ év májusában az egyházkerületi közgyülés határozata teremtette meg annak a jogi alapját. ${ }^{57}$ Mindezt abban a reményben tette, hogy majd a bölcsészeti fakultás is életre fog kelni hamarosan. Ez azonban csak a huszadik század első évtizedében valósult meg, amikor létrejött a Bölcsészetkari Dékáni Hivatal. ${ }^{58} \mathrm{Az}$ átmeneti időszakban a bölcsészeti tantárgyakat és tanszékeket a teológia, jog, valamint a tanárképző intézetbe mentették át. ${ }^{59} \mathrm{~A}$ bölcsészeti tantárgyak nagy része a gimnáziumi oktatásba került át, elöször az Entwurf, majd az Eötvös-féle reformok hatására, de az akadémia mindig igyekezett visszaállítani a Bölcsészeti Kart is. Ez irányú próbálkozás volt Vellentszéy Mór alkalmazása is, aki 1877-től tanított az 1879-80-as tanévig, majd ôt Bihari Imre volt sárospataki tanár váltotta. ${ }^{60} \mathrm{~A}$ változáshoz azonban pénz, jó szakemberek és nagyon erős egyházkerületi akarat volt szükséges, ami váratott magára.

A föiskolai reformok keretébe illett bele az is, hogy 1888-ban az akadémiai tanári kar elhatározta ${ }^{61}$ a tanévnyitó rektori beszéd megtartásának kötelezettségét, amelyet az akadémia igazgatója „az isteni tisztelettöl elkülönitve, a díszteremben tartott meg”. ${ }^{62} \mathrm{Az}$ első beszédet Erdős József, az 1888-ban az egyházkerület által az Újszövetségi Tanszékre megválasztott ifú tanár tartotta meg „A Biblia rendszere” címmel. ${ }^{63}$ A könyvtár, a gimnázium szervezeti kérdései és a tanári javadalmazás problémája is ismét előkerültek. Különösen mikor Sass Béla lett az akadémia igazgatója, az 1895-96-os tanévben. Öt a következő tanévre ismét megválasztották. Ez alatt a könyvtár rendezése megindult, a gimnáziumi internátus szervezeti szabályzata megfogalmazást nyert, tervrajza és költ-

${ }^{54}$ Bod Péter, Historia Ecclesistica, 3., Leiden-Lugduni-Batavorum, 1888-1890, 417.

55 Balogh, Adattár, i. m., 536.

56 A Tiszántúli Ev. Ref. Egyházkerület jegyzökönyve 1892-93, (1892. május hó., 172. szám), 127-128.

57 Balogh, Adattár, i. m., 540. Vö. még Zsigmond, i. m., 182.

58 Zsigmond, i.m., 182.

59 Uo., 181.

60 BALOGH, Adattár, i. m., 345.

${ }^{61}$ Akadémiai tanárkari jegyzökönyv az 1891-1892 iskolai évben (1891. július 1.-1892. június 28), 1892. jún. 28., 240. szám, (1-97 fols.) fol. 88. TtREL II. 1-d 50.

62 Balogh, Adattár, i. m., 540.

${ }^{63}$ „A debreczeni ev. ref. föiskola disztermében 1888. szeptember 11-dik napján, Erdös József theol. akad. tanárnak ünnepélyes beiktatása alkalmával elmondott beszédek. Erdös József, A Biblia rendszere." = 188889-diki évkönyv a Debreczeni Ev. Ref. Főiskola Akadémiai tanszakairól, szerk. Liszka Nándor, Debrecen, 1889, 7-47. 
ségvetése elkészült. Végül pedig a tanári javadalmazás megváltoztatására egy tanulmány is megjelent Sass Béla, Kovács Lajos, Dóczi Imre és Márk Endre aláirásával. A tanári javadalmazás felemelésének kérdését alaposabban szerette volna előkészíttetni a Gazdasági Tanács. Először Kola János javaslatát fogadták el, amelyet az egyházkerület 1897ben határozatban is rögzített, hogy már 1897-1898-as tanévben bevezethető legyen a fizetések emelése. ${ }^{64}$ Baczoni Lajos jogi dékán javaslatára az 1897-98-as tanévben, azaz harmadik alkalommal is megválasztották Sass Bélát. Ezt a megindult föiskolai reform folytatása biztosításának megtartása, vagyis a tanári fizetések rendezése, a főiskolai igazgatótanács megalakítása és működésének kialakítása, valamint más átalakítások rendezése egyaránt indokolta. ${ }^{65}$ Baczoni szorosan együtt dolgozott Sassal. Ö írta a debreceni főiskolai tanárok helyettesítéséről azt a szabályzatot, amely 1897-ben lépett életbe. ${ }^{66}$ Az egyházkerület egyértelműen támogatta a Kollégium korszerűsítését és a teológiai, valamint jogi tanárok véleményét és szakmai munkáját komolyan figyelembe vette. Baczoni „A kollégium korszerü fejlesztése" ${ }^{\text {"6 }}$ című munkája jól mutatja ezt. A jogakadémia helyzetéről a szükséges reformokról szóló rész is az ő dolgozata. ${ }^{68} 1907-b e n$ szervezték meg, ahogy utaltunk rá, a Bölcsészeti Dékáni Hivatalt, és ezzel háromra bővült az akadémiai karok száma. ${ }^{69}$ "A következö tanévben ez az átszervezés megtörtént és maradt az akadémia megszünéséig, 1914-ig. "70

Magyarországon református vagy akár közös, protestáns egyetem sohasem volt. Szükség lett volna rá, de a politikai erők nem tudtak úgy összefogni, hogy ez kialakulhatott volna. Ezenkívül a történelmi-politikai szituációk is akadályozták annak létrejöttét. Mégis a kollégiumi oktatás színvonala ugyanolyan nívós volt, mint a legtöbb nyugateurópai egyetemé, ahol orvosi kar is müködött. Amikor a változásokra lehetőség volt, a debreceni reformátusok léptek. Mintegy fél évszázadig vajúdott a Debrecenben 1914 őszén megnyílt egyetem létesítésének kérdése. Az új egyetem túl azon, hogy létében érintette a Debreceni Református Kollégiumot, a kollégium tanári karától és fenntartó testületétől kapta alapgondolatát, és e két testület volt legállhatatosabb szorgalmazója megvalósításának.

A hosszú tizenkilencedik század második felében történt meg az oktatási feladatok és az intézményrendszer átszervezése. Ezek a gyökereiben érintették a Debreceni Református Kollégiumot. A sok évszázadon keresztül féltve őrzött régi kiváltságokból egye-

${ }^{64}$ A Tiszántúli Ev. Ref. Egyházkerület 1897-dik évben Debreczenben tartott elsö közgyülésének jegyzökönyve, 1897. május 18-22. napjain, Kiadta TótH Sámuel, Debreczen, 1897, 149-169; 1897. május hó., 183. szám.

${ }^{65}$ Balogh, Adattár, i. m., 544.

${ }_{66}$ Uo., 535.

${ }^{67}$ BACzoni Lajos, A debreczeni ev.ref. fóiskola tanári karának munkálata a kollégium korszerü fejlesztése tárgyában, Debrecen, 1900.

${ }^{68}$ BALOGH, Adattár, i. m., 535.

${ }^{69}$ Zsigmond, i. m., 182. vö. BAlogh, Adattár, i. m., 540.

${ }^{70}$ CsohánY, i. m., 249. 
dül a lelkészképzésnek maradt meg az autonómiája. A többi nemcsak hogy átalakult, de még hihetetlen mértékű anyagi áldozatot is kívánt a gyülekezetektől és a református nemességtől. Mindez éppen a szabadságharc elvesztése után történt, és a megalázott magyar protestánsok megmutatták összetartó erejüket. A kollégium és az egyházkerület vezetőinek nagyon nehéz volt ilyen helyzetben megmaradni és józanul cselekedni. Ma már elmondható, hogy az Entwurf, majd a liberális magyar állam oktatáspolitikai rendelkezései jótékony hatással voltak a kollégium és benne a teológiai oktatás modernizációjára, amely már az átalakulás korában meghozta a maga első gyümölcseit.

\section{A teológiai oktatás történetének tanszéki áttekintése}

Az 1850-1914 közötti időszakban a teológiai tanszékek száma kétszeresére nőtt. Azonban így is messze mögötte maradtak a jogi és a bölcsészeti tanszékek számának a korszak végére. Nem jelentett hátrányt a külön tagozatokra válás sem a teológiának, mivel a három akadémia továbbra is oktatta egymás hallgatóinak a szakterületébe vágó tárgyakat. Az 1861 előtt a már létező három teológiai tanszék: a dogmatikai, irásmagyarázati és gyakorlati mellé 1866-ban egyháztörténeti, ${ }^{71}$ 1884-ben ószövetségi és 1913-ban a belmissziói katedrákat hozták létre. 1861 és 1914 között 13 rendes professzor működött a hat teológiai tanszéken. ${ }^{72}$

A tizennyolcadik században megjelenő racionális és majd következő században a liberális teológia hatására kialakuló modern vallástudományi kutatás, amely főként Németországból hatott a Debreceni Református Kollégiumban folyó teológia oktatására, a szakterületekre tagolódás korát jelentette. A felvilágosodás tudományos kutatásokat ösztönző hatását tükrözi az is, hogy 1798-ban felállították a különálló, de még mindig a teológia tanításával koordinált Filozófia Tanszéket. Ez egyben azt is jelentette, hogy most már a fontosságukban növekvő és egymástól is mind inkább elkülönülő természettudományi tantárgyak nem tartoztak tovább a filozófia körébe. A jogi tanfo-

${ }^{71}$ A Tiszántúli Reformált Egyházkerület Debrecenben 1864. évi április hó 7., 8., 9., 10., 11. és 12-dik napjain tartott közgyülésének jegyzökönyve, Debrecen, é. n., 17., 66. szám. 1864 áprilisában a közgyülés kimondta "hogy mihelyest pénzerönk gyarapodása engedi, legelsö feladatának fogja tekinteni azt, hogy theológiai intézetünk legalább egy új tanszék felállitásával fejlesztessék". A 67. szám pedig hosszan értekezik arról, hogy Révész Imre hogyan utasítja vissza április 10-dik havában kelt levelében a hittanárrá választását! Vö. uo. 17-18; A Tiszántúli Ref. Egyházkerület 1860. évi október havától kezdve bezárólag 1866. év végéig tartott közgyülései nyomtatásban megjelent jegyzökönyvének tárgymutatója, Debrecen, 1866, 15. Negyedik tanszék szervezése elvben kimondatik 1864. április 66. - Szerveztetik 1866. 22, (5.), 110 szám. Ezen tanszék betöltése iránti intézkedés, 1866. 111, 112 és tantárgyak új beosztása, 1866, 96.

72 Balogh, Adattár, i. m., 592. A teológia rendes tanárai: Aranyi István, Tóth Sámuel, Erőss Lajos, Lencz Géza, Révész Bálint, Könyves Tóth Mihály, Csiky Lajos, Menyhárt János, (Bethlendi Endre), Dicsőfi József, Sass Béla, Erdős József, (Révész Imre), Balogh Ferenc, Kiss Ferenc. 
lyam már előbb elvált a teológiai tagozattól, majd pedig újabb szakterületek kezdtek kialakulni. Czeglédi Sándor jól rámutatott, hogy a teológiai tudomány részekre osztódásának folyamata század második felében is tovább folytatódott. ${ }^{73} \mathrm{Ez}$ a folyamatot láthatjuk Debrecenben is.

Az elsö teológiai tanszék a kollégiumban a dogmatikai volt. ${ }^{74}$ Ezt a tanszéket Aranyi István (1793-1864) vezette 1822-től 1864-ig. ${ }^{75}$ Munkásságát Balogh Ferenc, aki még hallgatta őt, a 'rationalizmus szellemétől érintetett' oktatónak tartotta, aki „tisztán gondolkodó fö, [...] könnyü közlékenységü elöadó" volt, „ifjú tüzét mindvégig megtartotta”. ${ }^{76}$ Ezzel szemben Gaál Botond kiegyensúlyozott, azaz a racionalizmus és a hitvallásosság között hidat építő tanárként értékelte elődjét, aki „inkább megmaradt hitvallásos reformátusnak, egy kései ortodox teológusnak" ${ }^{77}$ 1864-1866 között Tóth Mihály a Dogmatika Tanszékhez tartozó keresztyén hittant, a különböző felekezetek tanrendszerét pedig Menyhárt János tanították, ${ }^{78}$ mert Révész Imre nem fogadta el az egyházkerület jelölését a tanszékre. ${ }^{79}$ A Dogmatika Tanszék oktatási arculatához tartozó egyháztörténetet, azonban 1864-65-ben ö oktatta. ${ }^{80}$ Öt követte a fiatal Tóth Sámuel ${ }^{81}$ (1839-1899), aki 1866-tól egészen 1899-ig oktatatta a dogmatikát. Tóth a kollégium Teológiai Akadémiáján végzett, seniori tisztet viselt (1863-64), és egyúttal segédtanár is volt. ${ }^{82}$ Már 1864-ben megválasztották rendes tanárnak, de csak 1886-ban foglalta el a katedráját. ${ }^{83}$ Két évig tanult Svájcban és Németországban négy egyetemen: Zürich, Heidelberg,

73 CZeglédi, i. m., 566.

74 A teológia a reformáció korában a dogmatikai tételek kibontását és bizonyítását jelentette, amelyet megtámogattak dogmatikai, filozófiai, dogmatörténeti, egyháztörténeti és a később bibliai teológiában kibontakozó módszerekkel, valamint a bibliaismerettel, azaz a Szentírás igazoló helyeivel. Így érthető, hogy a teológia (értsd dogmatika) volt az egyetlen tantárgy, amely köré csoportosult minden. Ennek a felfogásnak a lebontását és megváltoztatását látjuk a felvilágosodás megjelenésében a teológiában, amelyet a liberális teológia jutatott radikálisan érvényre az oktatásban. Meg kell említenünk azt is, hogy a tanszéki elnevezések tekintetében viták vannak a kollégium történetírói között. Egy biztos, hogy a tanszékeket betöltő teológiai tanárok tantárgyait egyrészt az örökölt helyzet, másrészt pedig saját érdeklődésük határozta meg. Végül, legalább ennyire fontos volt az intézmény vagy egyházkerület saját szempontja, amely esetleg a tanár által nem annyira preferált tantárgy oktatására késztette az adott professzort.

75 Balogh, Adattár, i. m., 410-411.

76 Uo.

77 GaÁl Botond, Kis tanszékböl nagy egyetemig, Debrecen, 2012, 90-91.

78 A Tiszántúli Ev. Ref. Egyházkerület 1864. október hó 7-10. napjain Debreczenben tartott gyülésének jegyzőkönyve, 12 szám, 3. TtREL, K439/4.

79 A Tiszántúli Ev. Ref. Egyházkerület 1863. október hó 3-án Debreczenben tartott gyülésének jegyzökönyve, 67. szám, 17-18. TtREL, K439/4.

80 Balogh, Adattár, i. m., 73-74. XXX.

81 Balogh Ferenc, Nekrolog - Tóth Sámuel, Debreceni Protestáns Lap (1899. április 29), 271. Balogh Ferenc, Tárca - Tóth Sámuel jellemzése, Debreceni Protestáns Lap (1899. április 29), 263.

82 ZovánYi, Lexikon, i. m., 655.

83 Balogh, Adattár, i. m., 74. 
Göttingen és Jéna. ${ }^{84} \mathrm{~A}$ fiatal Tóth Sámuel és Balogh Ferenc egyszerre kezdték el a teológiai tanári munkásságukat. ${ }^{85}$

Tóth 1869-ben a Tiszántúli Ref. Egyházkerület aljegyzője, majd pedig 1872-től főjegyzője lett. Az oktatás mellett az egyházjog és egyházi kormányzás irányába mozdult el alig három évvel professzorrá válása után. ${ }^{86}$ Munkássága is ezt tükrözi. Zoványi szerint: „A konventi gyüléseken mindenütt vive a vezetöjegyzöi teendöket [...]. Irodalmi téren éppen ilyen irányú elfoglaltsága miatt nemigen müködhetett." ${ }^{87}$ Csohány János is rámutatott, hogy: „az egyházi közszolgálat elhalmozta teendökkel. Különbözö egyházi, szervezeti egységek gyüléseinek volt a jegyzöje, fel egészen a zsinatig. Az egyházkerületnek végül föjegyzöje, azaz a püspök adminisztrativ helyettese lett. Számos nyomtatott jegyzökönyv; törvények és rendeletek gyüjteménye, ${ }^{88}$ egyházi névtár, ${ }^{89}$ adalékok a Tiszántúli Egyházkerület történetéhez ${ }^{90}$ került ki keze alól." "91 Tanulmányokat is írt a kollégiumi évkönyvekbe, és cikkeket jelentetett meg a Debreceni Protestáns Lapban, amelynek néhány évig szerkesztője is volt. Egyik korai főműve: „Az egyházakat s belhivatalnokokat legközvetlenebbül érdeklö országos törvények, kormányrendeletek, egyházkerületi rendszabályok és intézkedések kivonatos gyüjteménye" (Debrecen, 1875) volt. Rendszeres teológiai munkásságáról keveset tudunk. ${ }^{92}$ Dogmatikai munkásságát vizsgálva sok újat Aranyihoz képest nem hozott. Rendszeres teológiai tankönyvei kéziratban maradtak. Elődje 'masszív ortodoxiát' megjelenítő dogmatikai anyagát adta le. Az egyházkerületi teendői annyira lefoglalták, hogy tankönyvei „nem tükrözik a 19. század utolsó harmadának hazai és európai szellemiségét, abban sem a Jézus-kutatás, sem a modern tudományok kifejlödése nem jelenik meg".93 Ezt az ürt a dogmatörténetet oktató kollégája és barátja, az egyháztörténeti tanszéken munkálkodó Balogh Ferenc töltötte be. Ô rengeteget publikált ilyen témákban. Azonban a diákok az új tantervi rendezés során a Dogmatika Tanszéken maradt hittan és szimbolika mellett, teológiai enciklopédiát,

${ }^{84}$ ZovÁNYI, Lexikon, i. m., 655.

85 Tо́тн Sámuel, Beszédek, melyek a reformátusok debreczeni fötanodájában a hittanszakba beállitott Tóth Sámuel és Balogh Ferencz tanároknak az 1866. évi november 6-án az imatermében történt ünnepélyes beiktatásuk alkalmával tartattak, Debrecen, 1866.

${ }^{86}$ ZovánYI, Lexikon, i. m., 655.

87 Uo., 655.

${ }_{88}$ Tо́тн Sámuel, Egyházi törvények az evangeliom szerint reformált magyarországi keresztyén egyházban, Budapest, 1899, TtREK, L 2118.

89 Tóтн Sámuel, A magyarországi evangéliumi ref. egyház egyetemes névtára az 1886 évre, Budapest, [s. n.], 1887, TtREK F639i.

90 Tóтн Sámuel, Adalékok a tiszántúli ev. ref. egyházkerület történetéhez Debrecen, 1894, TtREK $2-14.860$.

${ }^{91}$ CsOHÁNY, i. m., 247.

92 Kovács Ábrahám, Hitvédelem és egyháziasság. A debreceni újortodoxia vitája a liberális teológiával, Budapest, L’Harmattan, 2010, 15-16. Érdemes lenne egy-egy professzor teológiai gondolkodását mélyen elemezni, hogy a kortárs teológiai szemléletekről képet kaphassunk. Itt egyértelműen további alapkutatásokra lenne szükség.

93 GAál Botond, Kis tanszékböl nagy egyetem, Debrecen, 2011, 95. 
apologetikát és Jézus élete című tantárgyat is tanultak. ${ }^{94}$ Ezenkívül Tóth Sámuelről elmondható, hogy nemcsak a Debrecenben megjelent Hitvalló Nyilatkozat egyik aláírója volt, hanem vitatkozott is a csodákat tagadó Bartha Mórral95 és az igen szélsőségesen liberális P. Nagy Gusztávval is. ${ }^{96}$

Öt követte Eröss Lajos ${ }^{97}$ (1857-1911) püspökladányi lelkész, aki 1899 szeptemberétől volt az „elméleti teológia” professzora 1908-ig. ${ }^{98}$ Erőss Lajos elödjeihez hasonlóan kollégiumi diák volt. A gimnáziumot és a teológiát is Debrecenben végezte, ahol a seniori tisztségre is megválasztották. Balogh Ferenc közvetítésével Bázelben és Berlinben tanult. Külföldi tanulmányútjáról hazatérve segédlelkész, majd rendes lelkészi szolgálatot végzett elöször Dévaványán, majd Kémer, Földes és Püspökladány gyülekezeteiben. Erőss egy ideig szerkesztette a Debreceni Protestáns Lapot is. 1908-ban tiszántúli püspökké választották Dicsőfivel szemben. 1909-ben Genfben részt vett a Kálvin-ünnepségen, és a genfi egyetem ekkor tiszteletbeli doktorai közé fogadta. ${ }^{99}$ A dogmatika professzoraként számos munkájával igyekezett betölteni az elődje által hagyott űrt. Rövid, mindössze kilencéves professzorsága alatt kiváló könyveket, tanulmányokat írt, melyekben a dogmatikai érdeklődést mutató Balogh Ferenc hatása érződik. Az 1895ben megjelent 'Apologetika' címü könyve mind a Jézus-kutatásra, mind pedig a természettudományos kérdésekre hitvalló válaszokat ad. Református hittudományt is írt 1911-ben. Foglalkozott a hitvallások, a krisztológia és az összehasonlító vallásteológia kérdésével is. 1906-ban németből lefordította a Buddhista katekézist. Ez a rendkívül tehetséges dogmatikus hamar püspök lett, majd pedig igen fiatalon, mindössze 54 évesen baleset következtében elhunyt.

Az ő utóda lett Lencz Géza (1870-1932) 1909-től. A fiatal tanár 1914-től 1932-ig az új debreceni egyetemen folyatta működését, mint a dogmatika és vallásbölcsészet tanára. ${ }^{100} \mathrm{~A}$ tanszék utolsó tanára még elődjétől is termékenyebb írónak bizonyult. A kollégium kiváló diákjából lett professzor. Külföldi tanulmányait Bécsben és Utrechtben végezte. Lencz „elödeihez képest sokkal jobban épitett a 19. századi nagy német teológusok gondolataira". ${ }^{101}$ Gaál Botond értékelése szerint Ritschl, Tröltsch és más mérvadó liberális teológusok hatása annyira érezhető volt a dogmatikai felfogásán, hogy a barthi, új reformátori teológia újnak hatott. ${ }^{102}$ Ezzel szemben Koncz elemzése rámutat: Lencz

\footnotetext{
${ }^{4}$ BALOGH, Adattár, i. m., 75.

95 То́тн Sámuel, Nyílt levél Bartha Mór sályii ref. lelkész és szatmár-egyházmegyei képviselö úrhoz, Evangyéliomi Protestáns Lap, 2. 47 (1876. november 24.), 385-387, 386. Részletesebben lásd Kovács, Hitvédelem..., i. m., 71.

96 То́тн Samuel, Húsvéti igazság kérdéséhez, Debreceni Protestáns Lap 2. 1882. június 5., 153-154. A vita kifejtését lásd Kovács, Hitvédelem, 165-170, valamint 188.

${ }_{97}$ Balogh, Adattár, i. m., 554.

98 ZovánYI, Lexikon, i. m., 181.

${ }^{99}$ CsohánY, i. m., 247.

100 ZovánYI, Lexikon, i. m., 368.

101 GaÁL, Kis tanszékböl, i. m., 102.

102 Uo., 102.
} 
állásfoglalása szerint a teológia egyházhoz hủ tudomány. Öt így Csiky Lajossal, Erőss Lajossal, az ún. egyházias kálvinizmushoz sorolja. ${ }^{103}$ "Mivel egyházhoz hü, ezért a hit és keresztyén bizonyosság, az üdvösség és a kijelentés változhatatlan tényein alapszik. Mivel pedig tudomány, ezért a történetben és életben meglátott vallásos igazságok megtagadására nincs joga, söt kötelessége, hogy a "tudomány és a hithüség" alapján az "Ige körüll lévö tudományos teendöket elvégezze, tudva azt, hogy az "Igén belülre" a tudomány behatolni nem képes, azt egyedül a hit és kegyelem munkája végezheti el." ${ }^{104}$ A Dogmatika Tanszék 1850-1914 között összesen négy professzort mondhatott magáénak.

Az írásmagyarázati tanszéken éppen a korszakunk kezdetén történt váltás. Erdélyi Józsefet a fiatal Menyhárt János ${ }^{105}$ (1850-1887) követte e tanszéken. Elöször 1850-ben helyettes hittanárként tanított, majd 1851. augusztus 15-én rendes tanárrá választották. ${ }^{106} \mathrm{~A}$ frissen végzett diákot és volt seniort (1849) kötelezték egy nyugati tanulmányi út megtételére, amely bevett kollégiumi gyakorlat volt. Így Göttingenben a keleti nyelveket oktató, híres Henrik Ewaldot hallgatta 1851-52 között. ${ }^{107}$ Csak külföldi tanulmányai után foglalhatta el professzori állását 1852-ben. ${ }^{108}$ Menyhárt harmincnyolc éven át oktatta a héber és a görög nyelvet, valamint az Új- és Ószövetséghez kapcsolódó tantárgyakat. ${ }^{109} \mathrm{~A}$ második tanszéken az ő 'korszaka' végén vált szét az írásmagyarázati tanszék külön Ó- és Újszövetségi Írásmagyarázati Tanszékre 1884-ben. Menyhárt az Újszövetségi Tanszéket tartotta meg. Látása megromlása miatt kényszerült volna nyugalomba 1887-ben, de az ószövetségi professzor, azaz a fiatalon elhunyt Bethlendi Endre halála miatt maradnia kellett. Akkor már vakon tanított kiváló precizitással. Fejből mondta az Újszövetség görög szövegét elöadásain. ${ }^{110}$ Kevésbé ismert tény, hogy Menyhárt volt a Debreceni Hitvallás (1875) valódi megszövegezője. ${ }^{111}$ A debreceni új ortodoxia meghatározó, szerény és nagy tudású tanára volt ő. Ebbe a tradícióba illeszkedett bele tanszéki utóda is, aki később majd az újszövetségi teológiai tudományokat oktatta.

Simai Erdös József (1888-1914) árva gyermekként végezte el a kollégium iskoláit. Az alma materben Balogh Ferenc, Menyhárt János voltak rá nagy hatással. Az osztrák fóvárosba Balogh Ferenc kapcsolatai révén jutott el. ${ }^{12}$ Ösztöndíjas diákként Bécsben

103 Koncz Sándor, Hit és vallás, i. m., 119.

${ }^{104}$ Lencz Géza, A keresztyénség vallástörténeti helyzete, Theologiai Szaklap (1910); Idézi Uo., Koncz, i. $m ., 119$.

105 Fenete Csaba, Menyhárt Jánosélete és munkássága. Kézirat. TtREK R3607.

106 BALOGH, Adattár, i. m., 53.

107 Uo., Fekete Csaba 1852/53-as tanévről tud, Balogh, a kortárs forrásokat szerző tanár, 1851/52-ről ír.

108 Fekete Csaba, Menyhárt János, (Debrecen), kézirat. fol. 2. TtREK, R3607.

109 Balogh, Adattár, i. m., 53.

110 Balogh Ferenc, Menyhárt János hittanár életrajza, Debreceni Protestáns Lap 20(1900/18), 274.

111 Kovács, Hitvédelem, i. m., Lásd A debreceni új ortodox hitvalló nyilatkozat létrejötte: a Debreceni Hitvallás címü alfejezetet.

112 Erdös József levele Balogh Ferenchez, Bécs, 1877. október 3. TtREK, R 1516. Szap.: 27.428. fol.1. Itt Balogh Ferencnek így címzi a levelét: „Nagytiszteletü úr, kegyes jóltevöm.” 
Eduard Böhl formálta teológiai szemléletét 1877-től. A bécsi professzor a hitvallásos ébresztő elberfeldi református lelkész, Kohlbrügge veje volt. ${ }^{113}$ Az ortodox kálvinizmust a gyakorlati életben is megélö elberfeldi gyülekezetben ismerkedett meg a lelkészi szolgálattal. ${ }^{114}$ Pancsovai majd újsóvéi lelkészként müködött. Ezekben a német nyelvű református gyülekezetekben szolgált debreceni professzorságáig. 1882-ben adta ki a Debreceni Protestáns Lapban a Heidelbergi Kátéről írt tanulmányát. ${ }^{15}$ Ekkor már javában dolgozott a káté fordításán. Balogh Ferenctől segítséget kért, hogy a Szilágyi Ferenc-féle kátét küldje el neki. ${ }^{116}$

Kiemelkedő tette az volt, hogy megjelentette saját fordításában a teljes Heidelbergi Kátét magyarul 1884-ben. Elegészen addig, „a XVIII. század második felében a cenzúra által megcsonkitottan adták ki Magyarországon”. ${ }^{117}$ Az újszövetségi tantárgyakat Menyhárt halála után, huszonhat éven át, 1888-tól kezdődően Simai Erdős József tanította, aki doktorátusát 1891-ben szerezte Bécsben. ${ }^{118}$ Erőss Lajoshoz hasonlóan 1909-ben a genfi egyetem tiszteletbeli doktori címmel tüntette ki. „Számos munkát bocsátott közre önálló kiadványban. Ezek túlnyomó része újszövetségi tárgyú. Termékeny cikkiró volt, sok szaklapnak dolgozott. " ${ }^{119}$ A debreceni egyetemről 1928-ban vonult nyugalomba. ${ }^{120}$

A harmadik teológiai tanszék is jelentős változáson ment keresztül a tárgyalt korszakban, Révész Bálinttól kezdve Tóth Mihályon át Csiky Lajosig. A gyakorlati teológia diszciplínáit már a puritanizmus korszakában is tanították. Azonban az egyházkerületi közgyűlés elég későn, csak 1844-ben ${ }^{121}$ állította fel ezt az igen fontos katedrát, amelyet a későbbi püspökkel, Révész Bálinttal töltött be. ${ }^{122}$ Révész a tanszéket 1855 -ig vezette, amikor is elcserélte a „jövedelmezöbb és nagyobb tekintélyt adó debreceni lelkészi tisztséggel". ${ }^{123}$

113 CsoHÁNy, i. m., 247. Zoványi lexikona tévesen 1878-at adja meg bécsi ösztöndíjas évként. Erdős már 1877-ben kint van Bécsben!

114 Erdös József levele Balogh Ferenchez, Bécs, 1879. március 19. és április 3. TtREK, R 1516. Szap.: 27.428. A levelezésből kiderül, hogy Erdős Genfbe szeretett volna menni vagy még Edinburghba! Végül is az anyagiak hiányában és Böhl hatására Elberfeldbe mehetett.

115 Tóтн Endre, A Heidelbergi Káté a magyar református gyülekezetekben és iskolákban = A heidelbergi káté története Magyarországon, Budapest, 1965, I., 293; Endős József, A Heidelbergi Káté története, Debreceni Protestáns Lap (1882), 51., 64., 75., 89., 97.

116 Erdös József levele Balogh Ferenchez, Pancsova, 1881. december 19. TtREK, R 1516. Szap.: 27.428. fol. 1.

117 VICTOR János, $A$ heidelbergi káté története = A Heidelbergi Káté és a II. Helvét Hitvallás, Budapest, 2010, 16-19.

118 Tanárkari jegyzökönyv (1888. szeptember 3. 10. szám), fol. 5. „Igazgató üdvözölvén a megnyitó új iskolai év (1888/89) ezen elsö gyülésén tanártársait, bemutatja Theologia Akadémiánknak újonnan választott tanárát, Erdös Józsefet, kérvén Isten áldását reá és müködésére."

119 SzInNyei József, Magyar irók élete és munkái, II., Budapest, 1893, 1411-1413.

120 ZovánYI, Lexikon, i. m., 179.

121 CsohánY, i. m., 212.

122 CZEglédi, i. m., 556.

123 CsohánY, i. m., 209. 
Utóda, Tóth Mihály (1857-1879) két évvel később, 1857-ben kezdte meg az oktatást mint professzor. ${ }^{124}$ Külföldi tanulmányai alatt Bécsben és Berlinben diákoskodott 1834 és 1836 között. ${ }^{125}$ Tóth Mihályt is ott találjuk a Debreceni Hitvallást aláíró teológiai tanárok között, amelyet a szélsőségesen radikális szabadelvű Ballagi-féle irányzattal szemben fogalmaztak meg. ${ }^{126}$ Azonban Balogh Ferenc értékes naplójának egy-egy részlete rámutatott arra, hogy ő inkább politizáló, helyezkedő, nem igazán hitvallásos egyéniség volt, aki ha csak lehetett, kerülte a nyílt konfrontációt. ${ }^{127}$

Tóth Mihályt Alsócsernátoni Csiky Lajos (1881-1914) követte, aki igazán Balogh Ferenc „lelki gyermeke” volt. Ö csak a teológiát végezte Debrecenben. ${ }^{128}$ A fiatal diák Edinburghban tanult a Skót Misszió ösztöndíjával két évet. Az ottani református egyházi ébresztő irány debreceni munkása lett. ${ }^{129}$ Csiky valójában ötvözte magyar kálvinista gyökereit a külföldi evangéliumi hatásokkal. ${ }^{130} \mathrm{Az}$ utóbbihoz mind a skót evangelikalizmust, mind pedig a német pietizmust segítségül hívta. Teológiai tanártársai közül kiemelkedett irodalmi termékenységével. „Elsősorban a gyakorlati teológia tárgykörét gazdagította írásaival, de egyháztársadalmi és belmissziói munkáival úttörő szerepet játszott ezen a téren. Életét és munkásságát megismerveméltatlan a két világháború között támadt lekicsinylő értékelése és lovagi címének gúnyolása, melyet kiemelkedő munkájáért kapott a királytól, akárcsak Erdős József a simai előnevet.”131 Hatalmas ívű teológiai munkássága nagyon sok diákra volt hatással. Számos területen hiánypótló szakkönyvet írt, és az evangélium hirdetésének, a magyar belmissziónak, Szabó Aladárhoz hasonlóan nagyformátumú fáradhatatlan harcosa volt. ${ }^{132}$

Az egyházkerület 1866-ban létrehozta az Egyháztörténeti Tanszéket. A tanszéket először 1864-ben említik az egyházkerületi jegyzőkönyvek. ${ }^{133}$ A tanítást eredetileg id. Révész Imre debreceni lelkipásztornak szánták, aki egy év tanítás (1864-65) után kérte felmentését. Ezután az oktatást a fiatal Balogh Ferencre (1866-1913) bízták, akit Menyhárt, Tóth Mihály és Tóth Sámuel tanártársaihoz hasonlóan külföldi tanulmányi út

124 Debreceni Heti Lap (1880/1). Idézi Balogh, Adattár, i. m., 72.

125 Balogh, Adattár, i. m., 71.

126 Kovács, Hitvédelem, i. m., 67-75.

127 Balogh Ferenc, Debreceni Naplo, Debreceni Napló, 1872. március 7., 336-337. DE kézirattár, Ms. 28/4.

128 CsOHÁNY, i. m., 247.

129 Koncz, Hit és vallás, i. m., 119.

${ }^{130}$ Kovács Ábrahám, A debreceni új ortodoxia tovább élése: Csiky Lajos belmisszió teológiai elképzelései, Mediárium 6. (2012/1-2), 75-99.

131 CsOHÁNY, i. m., 247.

132 Kovícs, A debreceni új ortodoxia..., i. m., 75-99.

${ }^{133}$ A Tiszántúli Reformált Egyházkerület Debrecenben 1864. évi April. hó 7., 8., 9., 10., 11. és 12-dik napjain tartott közgyülésének jegyzökönyve, Debrecen, [s. n.], é. n., 17., 66. szám. 1864 áprilisában a közgyülés kimondta, hogy: „mihelyest pénzerönk gyarapodása engedi, legelsö feladatának fogja tekinteni azt, hogy theológiai intézetünk legalább egy új tanszék felállitásával fejlesztessék". 66. szám. A 67. szám pedig hosszan értekezik arról, hogy Révész Imre hogyan utasítja vissza április 10-hón kelt levelében a hittanárrá választását! Uo., 17-18. 
megtételére köteleztek. „Balogh a teológiát Debrecenben végezte az 50-es években. Seniori hivatalt viselt. [...] Akkor még magyar irodalmár akart lenni." ${ }^{134}$ A fiatal Balogh franciaországi, angliai és skóciai peregrinációja (1863-1865) során szerzett evangéliumi tapasztalatai meghatározóvá váltak később a teológia és kollégium lelkiségére nézve. ${ }^{135}$ A skót református evangelikalizmust, a francia Réveil és a német pietista hatásokat a magyar kálvinista hagyományokhoz igazította, és sajátos, mérsékelt ortodoxként adta tovább élő és hitvalló kegyességével diákjainak, amelynek jelentőségét diákok százainak munkássága bizonyította. ${ }^{136}$ Végül is igazán ővele indult el a negyedik Teológiai Tanszék. A fiatal tanár 1865-ben kezdte meg munkásságát, mint ideiglenes tanár, majd 1866-ban rendes tanárként alkalmazták. ${ }^{137}$ Csohány János értékelésében a következőket olvassuk: „Élete a teológiatörténet, kegyességtörténet és az iffúság sokoldalú, öntevékenymunkára nevelésében korszakalkotó.” [...] „1861-1914 között nem volt teológiai tanár Debrecenben, aki annyit publikált volna, mint ö. Nyomtatott munkáinak száma meghaladja a háromszázat. Mindenekelött az egyház-, a magyar történetet és az irodalomtörténetet müvelte, de más jellegü, ismeretterjesztö irások is találhatók közöttük. Rendkivüli népszerüségét mutatja, hogy az iffúság 1909-ben Erdös Károly senior kezdeményezésére márványtáblával jelölte meg Balogh Ferenc kedvenc elöadótermét. E terem ma is az ö nevét viseli." [...] „Halála után az egyetemmé válásig már nem töltötték be katedráját."138

Az egyházkerületi döntés értelmében 1884-ben megszervezödött az önálló Ószövetségi Írásmagyarázat Tanszék is, amely az ötödik teológiai katedra lett. „Ezzel elválasztotta az Irásmagyarázati Tanszéktöl, amelyet újszövetségi irásmagyarázatinak minösitett át". ${ }^{139}$ Mint láttuk, eddig egyetlen tanszék, az Írásmagyarázati Tanszék látta el mind az ószövetségi, mind pedig az újszövetségi tantárgyak oktatását. A régi Îrásmagyarázati Tanszéket Újszövetségi Írásmagyarázat Tanszékké minősítették át, az addigi professzor, Menyhárt János pedig a tanszéken maradt. Az újonnan alakult Ószövetségi Tanszék első professzora Bethlendi Endre ${ }^{140}(1850-1888)$ lett 1884-től. Ö a kollégium zseniális növendéke volt, aki végigjárta a diáktisztviselők útját a seniorságig, több kollégájához hasonlóan. ${ }^{141}$ Már diákkorában ő is aktívan részt vett a Balogh által kezdeményezett

134 CSOHÁNY, i. m., 248.

135 Ötvös László, Balogh Ferenc életmüve (1836-1913), Debrecen, 1997, 119-128.

136 Uo., 129-132. „Balogh Ferenc mint kollégiumi nevelo””. Ez a szakasz az egyetlen összefoglalás, amely Balogh Ferenc diákokra tett hatását igyekszik összefoglalni. A nagy teológus és történész élettörténetének és a diákokra, valamint a debreceni ébredésre gyakorolt hatásának kikutatásával még mindig adós a református egyháztörténet!

137 A Tiszántúli Reformált Egyházkerület Debrecenben 1866-dik évi október hó 2-6-dik napjain tartott második közgyülésének jegyzökönyve Debrecen, é. n., 10. Említi a 111., 112., 113. számokat, azaz tárgypontokat, amelyek elmondják Balogh Ferenc egyöntetű megválasztását. Lásd még ZováNYI, Lexikon, i. m., 42 .

138 CsOHÁNy, i. m., 247-8.

139 Uo., 248.

${ }_{140}$ Zoványi, Lexikon, i. m., 76. Ö Menyhárt veje volt!

141 Csohány, i. m., 248. 
HÖT-ben, amelynek 1875-ben elnöke is volt. ${ }^{142}$ Négy évet (1876-1880) töltött külföldi ösztöndíjasként Edinburghban, Bázelben és Genfben. Érdemes odafigyelni arra, hogy mindegyik város a belmissziónak és az ébredési mozgalmaknak a fó centrumai voltak. Edinburgh a skót evangelikalizmus fellegvára, Bázel a német pietizmus egyik fö központja, míg Genf a Réveil meghatározó, a skót Robert Haldane ${ }^{143}$ hatását mutató helye volt Henri Merle d'Aubignével az élen. ${ }^{144}$ Külföldi tanulmányai alatt, ahogy levelezéséiből kitünik, őt is mélyen foglalkoztatták a dogmatikai és hitvallási kérdések. Leveleiben számtalan alkalommal részletesen összefoglalja az olvasott művekről saját, önálló véleményét. ${ }^{145}$

1880-ban tért haza, mert segédtanári állást kapott a Teológiai Akadémián az 188081-es tanévre. ${ }^{146}$ Csiky megjegyzi, hogy Bethlendi volt a legtöbbet külföldön tanuló magyar teológus abban az időben, ez idő alatt egyébként rengeteg könyvet gyüjtött össze. Kezdetben vallásbölcsészeti és angol nyelvi tanár, továbbá 1882-től még franciát is tanít. 1883-tól ószövetségi exegézis és bibliai teológia oktatását is rábízzák. Az 1884ben felállított ötödik tanszéknek, első rendes tanárává egyhangúlag választják meg. Tanszékfoglaló beszéde Isten és Izrael címmel jelent meg. ${ }^{147}$ „Három nagyobb tanulmányt közölt a Debreceni Protestáns Lapban, egyet az akadémiai értesitöben." 148 Tanulmányaiban a filozófiai teológia nagyon egyéni felfogását láthatjuk. Eredeti gondolkodó volt, aki képes volt a rendszeralkotásra, de annak kiforrását betegsége megakadályozta. Megbízatását sajnos egy évvel később, az 1886-87-es tanév első félévének végeztével vissza kellett vonni rossz elmeállapota miatt. ${ }^{149}$ Ápolása kezdetben rokonainál történik,

${ }^{142}$ A föiskola hittanszaki önképzö társulatának jegyzökönyve, 2. kötet, fol., 116. Lásd 1875. nov. 5 aláíását., TtREL, II. 24. h. 2.

143 A. L. Drummond, Robert Haldane at Geneva 1816-17, Records of Scottish Church History Society 9(1947/2), 69-82.

144 Timothy C. F. STunt, From Awakening to Secession: Radical Evangelicals in Switzerland and Britain, 1815-1833, Edinburgh, 2000. Lásd még Kovács, Ábrahám, The History of the Free Church of Scotland's Mission to the Jews in Budapest and its impact on the Reformed Church of Hungary 1841-1914 = Studien zur interkulturellen Geschichte des Christentums vol. 140, Frankfurt am Main-BerlinBern-Oxford-Wien, 2006, 61. Lásd még GYőri János, Emlékbeszéd Kálvin felett, Debrecen, TtREK, 2008.

145 Bethlendi Endre levél Balogh Ferenchez, Edinburgh, 1877. október 29., fols. 12. A tizenkét oldalas levélben French, On parables, Van Osterzeee, Dogmatika, Westcott, Farrar Life of Christ, Lightfoot, Life of Christ, Pál apostol leveleinek magyarázata van megemlítve. Ilyen összefoglalásokra ritkán van példa a Baloghnak írt levelekben. Vö. Erdős, Csiky, Dicsőfi, Márk stb. diákok által írott levelekkel.

146 A Debreczeni Ev. Ref. Föiskola disztermében 1888. szeptember 11-dik napján, Erdös József Theol. Akad. tanárnak ünnepélyes beiktatása alkalmával elmondott beszédek = 1888-89diki évkönyv a Debreczeni Ev. Ref. Főiskola Akadémiai tanszakairól, szerk. Liszka Nándor, Debrecen, 1889, 5.

147 Bethlendy Endre, Tanári székfoglaló értekezésböl mutatvány, Debreceni Protestáns Lap 4. 1884. október 5., 225.

148 Csohány, i. m., 248.

149 A Debreczeni Ev. Ref. Főiskola dísztermében 1888. szeptember 11-dik napján, Erdős József theol. akad. tanárnak ünnepélyes beiktatása alkalmával elmondott beszédek. Tóth Sámuel emlékbeszéde Betlhendi Endre felett = 1888-89-diki évkönyv, i. m., 5-7. 
majd Budára kerül, a Lipótmezei Tébolydába, ahol 1888. február 15-én halt meg harmincnyolc évesen. ${ }^{150}$ Felesége Menyhárt Kornélia, aki Menyhárt János egyetemi tanár lánya volt, egy fiúgyermekük született. ${ }^{151}$

A tanszék következő professzora Dicsöfi József (1859-1920) volt.. ${ }^{152}$ Menyhárt János már 1883-ban kiszemelte utódjának." ${ }^{153}$ Végül is 1887-ben választották meg utódjául az Újszövetségi Tanszékre. ${ }^{154} 1888$ tavaszától azonban Dicsőfit áttették, elöször Bethlendi helyettesítésére az Ószövetségi Tanszékre. ${ }^{155}$ Ezen a tanszéken véglegesítették. Dicsőfi mint kollégiumi diák a Balogh Ferenc által alapított HÖT-ben tevékenykedett, amelynek Erőss Lajossal együtt egyik húzó embere volt. Seniorságot viselt. A fiatal diák itthon és Lipcsében és Marburgban készült az írásmagyarázati katedrára, igaz akkor még nem sejtve annak beteljesülését. Külföldön a hitvallásos, zsidómissziót is támogató Franz Delitzschnél tanult elöször, akivel Balogh Ferenc a Skót Misszió által személyes és szoros kapcsolatba került. ${ }^{156}$ Mindössze három évet oktatott a Teológiai Akadémián. Dicsőfi irodalmi munkássága is inkább a gyakorlati lelkészkedés körébe vág. „Aranyszájú" papnak emlegették a kortársak. Nem véletlen ez, hiszen a Kossuth utcai református gyülekezetbe távozott lelkésznek. Így az Ószövetségi Írásmagyarázati Tanszék megürült 1890-ben. Az egyházkerület rendezte a két exegetikai tanszék sorsát. ${ }^{157}$ Pályázatot írt ki, amelyet Sass Béla nyert meg a krassói Ferenczi Gyula ellenében. ${ }^{158}$ Az Újszövetség Exegézis Tanszéke Erdős Józsefé maradt. ${ }^{159}$ Az egyházi közéletben egyházkerületi föjegyzőségig emelkedett. Utca viseli nevét Debrecenben. ${ }^{160}$

Dicsőfit követte Sass Béla, aki Menyhárt után 24 évet (1890-1914) oktatott az Ószövetségi Tanszéken. Mint fiatal diák tevékenyen részt vett a HÖT-ben. Elöször alelnökként, majd pénztárosként serénykedett. Egy ideig még a Közlönynek is ő volt a szerkesztője. 1886-87-ben seniorságig emelkedett, majd pedig gimnáziumi segédtanár is lett. Balogh Ferenc és Bethlendi Endre mellett ő tartózkodott a teológiai tanárok közül legtöbbet külföldön, hiszen összesen három évet töltött Berlinben, ahová 1887.

150 Csíky Lajos, Bethlendi Endre, Debreceni Protestáns Lap 8. 1888. február 18., 58.

151 Dombi Lajos, Nekrolog, Debreceni Protestáns Lap, 8. 1888. február 25., 64-66.

152 A Tiszántúli Ev. Ref. Egyházkerület 1885. április hó 23-28. napjain Debreczenben tartott elsö gyülésének jegyzökönyve, szerk. Tóth Sámuel, Debrecen, 1885, 59. Dicsőfi Balogh Ferenc közeli tanítványi köréhez tartozhatott, hiszen 1885-ben kezelő könyvtárnokként dolgozott a föiskolai könyvtárban.

153 CsohánY, i. m., 248.

154 Tanári székfoglalóját 1887. szeptember 11-én tartja „A synoptikus evangeliumok kritikája és apologiája” címmel, mely később nyomtatásban is megjelent, lásd Debreceni Protestáns Lap (1887/38), 331-333; (1887/39), 340-342; Föiskolai Évkönyv 1887/88, i. m., 5-63.

155 Balogh, Adattár, i. m., 349.

${ }_{156}$ Dicsöf József levele Balogh Ferenchez, Lipcse 1883. december 18. fols. 8, (fols. 4-5.), TtREK, R1516.

${ }^{157}$ Az Evang. Ref. Tiszántúli Egyházkerület 1890. június hó 2-6. napjain Debreczenben tartott elsö gyülésének jegyzökönyve. Kiadta Tótr Sámuel, Debreczen, 1890, 1890. június hó, 143. szám, 97-99.

158 Uo. 161. szám, 111.

159 Balogh, Adattár, i. m., 544.

160 CsohánY, i. m., 248. 
október 10-én iratkozott be. ${ }^{161}$ Ő már nemcsak a Révész, Menyhárt és Balogh nevével fémjelzett debreceni új ortodoxia hagyománnyal találkozott és a Csiky-féle egyházias kálvinizmustól tanult, hanem nyelvészeti érdeklődése miatt hatott rá a liberális teológiai is. A német fővárosban a liberális Otto Pfleiderer, rendszeres teológus Baurtanítvány, a szintén Baur-tanítvány, August Dillmann, valamint azok iskoláját ellenző Bernhard Weiss előadásait hallgatta. ${ }^{162}$ Sass huszonöt évesen lett professzor. Néhány nagyobb, jobbára ószövetségi dolgozata jelent meg részben önállóan, részben évkönyvben. Szerkesztette a Debreceni Protestáns Lapot az egyházi közélet tevékeny munkásaként. Tóth Sámuelhez életútja két dologban nagyon hasonlított. Egyrészt igen fiatalon lett teológiai tanár, másrészt különböző testületek vezető embere lett. Többek közt a Kollégiumi Igazgatótanácsnak, az Egyetemes Konventnek és az 1904-1907 között ülésezett törvényalkotó zsinatnak a jegyzője volt. „A konventi és zsinati jegyzőkönyvek nyomtatásban történö kiadása és az 1907. évi magyar református törvénykönyv nyomdába bocsátása az ö feladata volt. Kitünö adminisztráló tehetsége és nagy munkabirása volt." 163 Munkásságát mint kinevezett egyetemi tanár 1914-től a későbbi Debreceni Tisza István Tudományegyetemen folytatta, amikor 1928-ban 'megkapta a hazahívó szót az ő mennyei urához. ${ }^{164}$

A tanszékek közül időrendi sorrendben, de nem jelentőségben a legutolsó volt e korszakban a Belmissziói Tanszék létesítése. Ez lett a hatodik teológiai katedra, amelyet egyházkerület1913-ban létesített a gróf Dégenfeld-Schomberg Imre fógondnok gyermekei által létesített alapítványból. ${ }^{165}$ Első professzora az a Kiss Ferenc (1913-1933) püspökladányi esperes lelkész volt, aki a belmisszió, a társadalmi felemelkedés munkaterületén már bizonyította ismereteit és rátermettségét. A teológiát végezte Debrecenben. Volt senior és bécsi ösztöndíjas éve után hamarosan földesi, majd püspökladányi lelkészként szolgált. Ott „ifjúsági egyletet, református népkönyvtárat, református dalárdát, télen felolvasóesteket, gazdakört, hitelszövetkezetet, földbérlö szövetkezetet, 300 szegény családnak házépitési akciót szervezett, terjesztette a Bibliát és más egyházi kiadványokat". ${ }^{166}$ Bevezette az esti bibliamagyarázatot. A debreceni egyetem első rektorává őt nevezte ki a kultuszminiszter 1914-ben. ${ }^{167} \mathrm{Az}$ ő életén is látható a nagyformátumú Balogh Ferenc nevelői hatása, hiszen rajta keresztül kerül ki Böhlhöz, mint Erdős Bécsbe. ${ }^{168}$ Kiss 1931-ben megszervezte és 1945-ben bekövetkezett haláláig vezette az Országos Református Szeretetszövetséget. Irodalmi művei többnyire beszédek és irodalomtörténeti értekezések, cikkek, de írt - Csiky Lajoshoz hasonlóan - bevezetést a lelki gondozás és a belmisszió elméletébe és más elméleti teológiai dolgozatokat is.

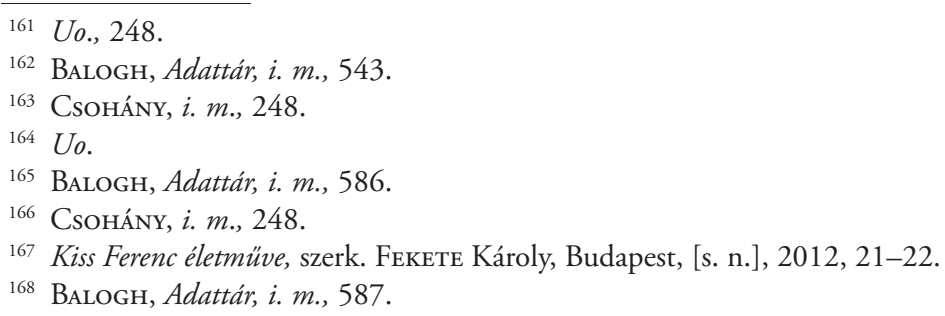


A teológiatanárok közül minden volt debreceni diák részt vett az évszázadokon át működő peregrinációban. A debreceni oktatás sajátossága többek között abban állt, hogy minden egyes diák a kollégiumban tanult, azaz hazai nevelés volt, és ez közvetetten is biztosította az ortodox teológiai szemlélet fennmaradását. A 19. század második felében a katedrák száma egyértelműen bővült, és a tanárok szakmai arculata egyre rétegezettebbé és specifikusabbá vált. A korábban kizárólagos német, holland és svájci befolyás mellett megjelent a skót is, amely komoly hatást fejtett ki a debreceni teológián a diákokkal talán legtöbbet foglalkozó Balogh Ferencen, majd Csiky Lajoson, Bethlendi Endrén, Erdős Józsefen és Kiss Ferencen keresztül egészen Erőss Lajos püspökig. Emellett a német és svájci szálon is inkább a hagyományos, ortodox nézeteket valló diákok kerültek be a tanári karba, többé-kevésbé megtartva az ortodoxia hitvallásokat értékelő nézeteit. 1850 és 1914 közötti időszakban a mérsékelt teológiai ortodoxia és az egyházias kálvinizmus uralta a teológiai oktatást Debrecenben. 